\title{
NILS AND THE SOCIAL MOTHER AS A MIGRATING GOOSE
}

\author{
Anna Bohlin \\ Stockholm University \\ anna.bohlin@gender.su.se
}

\begin{abstract}
This contribution explores the ideals of citizenship in Selma Lagerlöf's Nils Holgersson's Wonderful Journey through Sweden (1906-1907). ${ }^{1}$ The social morals taught by Akka the goose - possibly one of the world's most famous female leaders - influenced Swedish school children and children around the world for decades. The analysis shows that Akka is an example of Ellen Key's concept of the 'Social Mother', promoting early 'folk ideology'. Taking the cue from Sara Ahmed's theory of 'affective economies', I investigate the function of fear in building a nation. A comparison with Rudyard Kipling's The Jungle Book (1894-1895) makes clear that although power struggle is a common theme in these two children's books, fear has an equally important but opposing role in each book in the founding of society. In The Jungle Book, fear installs a constitutional order and guarantees Man's supremacy over the animals, while fear in Nils Holgersson fosters community across different species; in Lagerlöf's affective economy, fear does indeed establish boundaries, but also functions as a means to transgression and as a source of social virtues. Contrary to Berggren and Trägårdh's claim that independence is at the core of 'the Swedish ideology', the experience of dependence and fear is necessary to achieve a responsible form of independence. Nils's progress reflects a psychologically informed process of development of moral virtues in several steps, initially motivated by self-preservation, then self-assertion, habit, and finally by an ethics of love. The story also portrays different forms of government, opting for democratic rule that is intent on creating a home for the people. The nation-building function of fear is to balance the power struggle for a citizen's right to recognition with an insight into the vulnerability of life and the need for transgressive love.
\end{abstract}

\section{Keywords}

Selma Lagerlöf, Nils Holgersson's Wonderful Journey through Sweden, citizenship, social motherhood, affective economies

Nils Holgersson's Wonderful Journey through Sweden (1906-1907) by Selma Lagerlöf (18581940) has crossed borders in a wonderful way. The reading book taught at primary school depicts the geography of Sweden and has been surprisingly successful in transgressing national,

\footnotetext{
${ }^{1}$ This is an abbreviated and partly rewritten version of Anna Bohlin (2018). Нильс Хольгерссон и национализм. Transl. into Russian by V.A. Petrunicheva. In T. Torstendahl-Salytjeva, Marina O. Dubovitskaya \& Diana B. Koblenkova (Eds.), Секреть мастерства: Этика, религия, эстетика в творчестве Сельмь Лагерлёф (The Secrets of Artistry: Ethics, Religion, and Aesthetics in Selma Lagerlöf's Authorship). Moscow: The Russian-Swedish Center at the Russian State University for the Humanities, 25-46. I am grateful to Stephen Svanholm and Henrik Bohlin for proofreading the text on very short notice.
}

Tijdschrift voor Skandinavistiek 36(2), 2018/19 (0)) (EY 
political and media borders alike. Translated into approximately 60 different languages and published in Tsarist Russia as well as in the Communist Soviet Union, this story of an enchanted boy was adapted into a cartoon for the first time in the Soviet Union in 1955, while children of our own time primarily make contact with Nils by means of an animated series produced in Japan in 1980. There are numerous studies of different translations and adaptations of Nils Holgersson (see e.g. Nikolajeva, 1991; Desmidt, 2001; Hartlová, 2014; Berry, 2014; van Elswijk, 2014; Surmatz, 2014; Heggestad, 2012; Smedberg Bondesson, 2016), but I will focus on the transgression of borders in the story, as a prerequisite for a national community. The aim of the article is to explore the ideals of citizenship expressed in the social morals taught by the leading goose, Akka - possibly the world's most famous female leader - and specifically to investigate the function of fear.

In a study that has received much attention, the historians Henrik Berggren and Lars Trägårdh sought for the historical roots of what they call 'the Swedish ideology', arguing that contrary to the image of Sweden as a socialist country, the development of the Swedish welfare state was guided by a 'sometimes extreme individualism' (Berggren \& Trägårdh, 2015, 22). The emphasis on independence and the individual's emancipation from the family, they argue, led to an alliance between the individual and the state, and a conception of love based on autonomy, excluding economic dependence (Ibid.). Curiously, they do not mention Nils Holgersson's Wonderful Journey through Sweden - a schoolbook that moulded generations of Swedish citizens for at least half a century (Nordlund, 2005, 102). In Lagerlöf's story, however, contrary to Berggren and Trägårdh's claim, independence is the vice threatening society.

Firstly, I will present Akka as an example of Ellen Key's concept of 'Social Motherhood', before moving on to an analysis of fear, informed by Sara Ahmed's theory of 'affective economies', and a comparison of Nils Holgersson to Rudyard Kipling's The Jungle Book (18941895). Finally, the crossing of borders, as a fundamental experience for the development of social morals, will be highlighted. Usually, Lagerlöf's stroke of genius is considered to be the idea of turning a boy into an elf flying over the country on the back of a goose, but it can be argued that her truly original idea is Akka: a migrating goose, carrier of the most fundamental, unifying glue of the nation.

\section{'Social Motherhood'}

The Swedish notion of the folkhem, 'the people's home', is usually associated with the Social Democrats and dated back to 1928. However, at this time, the concept of the folkhem and the various ideas constituting it had already long been prominent in the public debate, not only among Socialists, but across all political parties. In contrast to political ideas, which build on principles of individual autonomy, the ideology of the folkhem is collectivist, in the sense that the individual is understood as formed by the community (Lagergren, 1999). Although Berggren and Trägårdh argue that this is a simplistic analysis, disregarding the individualistic tenet (Berggren \& Trägårdh, 2015, 61), they do not dispute the fact that moral virtues are the foundation of the folkhem (Lagergren, 1999; see also Altén, 1983).

One of the advocates of the early 'folkhem ideology' was the controversial writer Ellen Key (Lagergren, 1999). Lagerlöf and Key disagreed on many things (Weidel, 1972), including the notion of the gendered body. Key relied on an evolutionist framework that located societal

Tijdschrift voor Skandinavistiek 36(2), 2018/19 (co) EY

Except where otherwise indicated, the content of this article is licensed and distributed under the terms of the Creative Commons Attribution 3.0 License, which permits unrestricted use, distribution, and reproduction in any medium, provided the original work is properly cited. 
progress primarily within the reproductive body. ${ }^{2}$ Certainly, many of Lagerlöf's novels depict traditionally gendered civic virtues, but these virtues may well be expressed by either gender, thereby undermining the heteronormative production of sex (Bohlin, 2008). Despite this difference, they did agree on the demand for motherliness in the government of society. Three years before the publication of Nils, Ellen Key published her essay 'Social Motherhood', where she argues that society needs motherliness - not necessarily more mothers, but motherliness; in Key's definition, 'an immediate feeling for all that is weak and in need, all that is budding and becoming' (Key [1903] 1923, 18; Lindén, 2002). In her 'home duties', Key writes, the social mother should foster the abilities later to be conducted in public life: she must 'develop the qualities of a statesman, a spiritual guide, a general, a legislator, an economist, an artist, to maintain the calm and strong authority by which all will be ruled in thinking they follow their own will. Thus, she may let the sun bring out everybody's best qualities [...].' (Key [1903] 1923, 39, my translation). A leader in all respects, Akka is the social mother.

Akka is a Sami word for 'old mother' (Edström, 2002, 344), and Lars Elenius (2005) has interpreted her and her fellow wild geese, named after Finnish numerals, as allegories of the mishandling of the ethnic minorities in the North of Sweden. Bjarne Thorup Thomsen (2007) has, on the other hand, stressed how the flock's flight creates the nation by linking its separate parts, and that the flock itself is an example of a hybrid gathering of individuals forming a community in developing solidarity with one another. Mobility and the "import of "otherness"" are at the heart of Lagerlöf's nationalist enterprise, Thorup Thomsen argues (2007, 94). Regardless of whether Akka represents the Sami people as an ethnic minority or the entire Swedish nation, she remains a migratory bird; for her, Sweden is one of several countries serving as both a transit and as a homeland. Furthermore, for over one hundred years, she has impressed social morals on millions of children around the world - a social morality taking its cue from fear. ${ }^{3}$

\section{Fear}

The harmonising task of the social mother seems at odds with a story constantly concerned with a power struggle: in Nils Holgersson the animals fight each other, and incite each other with insults. Human beings fight each other and nature to gain power over the forest, mineral resources and even water. Even the landscape fights with itself: the sea against the shore, one river against the other. Motion is always depicted in terms of power in Lagerlöf's work, and self-denial is a sure sign of madness and death throughout her authorship (Bohlin, 2008; see also Thorup Thomsen, 2007, 122). Action arising from struggle, on the other hand, is life, and in her nation-fostering schoolbook, the struggle for power encourages the citizen to demand recognition.

\footnotetext{
2 'Gendered' and 'reproductive body' are here used as analytical terms. For an extended discussion on Key's apprehension of the body, see Bohlin, 2008; Lindén, 2002.

${ }^{3}$ It should be stressed, however, that politically corrected translations are not unusual and, generally, large parts of the story are omitted and new scenes added, the most conspicuous example being the first translation of Nils into Czech, where the geese decide to stay in Southern Bohemia (Hartlová, 2014).
}

Tijdschrift voor Skandinavistiek 36(2), 2018/19 (co) EY

Except where otherwise indicated, the content of this article is licensed and distributed under the terms of the Creative Commons Attribution 3.0 License, which permits unrestricted use, distribution, and reproduction in any medium, provided the original work is properly cited. 
This is a theme that resonates with The Jungle Book by Rudyard Kipling - a great source of inspiration to Lagerlöf (Ahlström, 1958). Björn Sundmark $(2009 ; 2008)$ draws attention to The Jungle Book in a comparison of the ideas of citizenship in Nils Holgersson and Robert BadenPowell's Scouting for Boys (1908). Although Lagerlöf was a pacifist and the aim of the founder of the Scout movement was to prepare the British Empire for war, they both understood that the crucial need to secure the future of the nation required that the characters of citizens be built through experience. Nevertheless, Sundmark does not elaborate on the comparison with The Jungle Book. Several motifs in Lagerlöf's story may be tracked down to Kipling's, including the constitutional democratic order of the animal peoples (Ahlström, 1958), but I will investigate the significance of fear.

In The Cultural Politics of Emotion (2004), the philosopher Sara Ahmed has shown how emotions such as love, hatred and fear engender a national community, in what she calls 'affective economies'. Emotions are economic in the sense that they circulate and intensify by adhering to certain objects, transforming bodies: 'the fear works through and on the bodies of those who are transformed into its subjects, as well as its objects' (Ahmed, 2014, 62). She analyses how fear in our time of terror and war on terror creates national borders, particularly borders between those under threat and those threatening. However, fear is invested with a somewhat different meaning in the affective economies of The Jungle Book and Nils Holgersson respectively.

Kipling's book is a study of the imperialistic struggle for power. The superiority of man is instantly established, as baby Mowgli's spectacular future is predicted: Man is weak, but through cunning and fearlessness will triumph (Kipling, [1894] 1900, 10-22). The gaze as an instrument of power is a recurrent theme: Mowgli stares at the animals until they lower their gaze and submit to him. Fear is also central to the political myth presented in the chapter 'How Fear Came'. In the beginning, all animal peoples were one people and did not fear each other. A court of justice was established to settle conflicts, but a tiger forgot his authority as a judge and killed another animal. With death entering the Garden of Eden, order and respect for the law was lost. This disorderliness had to be defeated by subjecting the animals to a law they could not break - fear. Fear was the master they could not defy, and after having encountered fear, the animals also became afraid of each other and no longer dared to sleep near each other (Kipling, 1895, 14-16). Indeed, fear does create boundaries in precisely the way Ahmed has in mind, yet fear also establishes the law. The function of fear in this affective economy is the subjection to constitutional order. However, fear turns out to be personified in Man, which explains why Mowgli is never afraid and why he therefore becomes the Master of the Jungle. Ultimately, the animals' fear is the guarantee of Man's absolute power.

In Nils Holgersson, fear has an equally important task in creating society, but through opposite means. Fear is hardly a virtuous emotion, but in Lagerlöf's book it proves to be absolutely necessary for engendering virtue and thereby the nation. In the beginning, Nils, like Mowgli, is never afraid - although in this story his independence is his greatest problem, as he can be cruel to the animals without retribution. As Anna Smedberg Bondesson notes in a discussion of shame and guilt in Nils Holgersson and Pinocchio, Nils's sense of guilt only grows slowly, but in the end it enables him to take responsibility (Smedberg Bondesson, forthcoming 2018). When transformed into an elf, he becomes vulnerable, dependent, and

Tijdschrift voor Skandinavistiek 36(2), 2018/19 ((c)) EY

Except where otherwise indicated, the content of this article is licensed and distributed under the terms of the Creative Commons Attribution 3.0 License, which permits unrestricted use, distribution, and reproduction in any medium, provided the original work is properly cited. 
frightened. As Akka informs him, such small creatures have many enemies. Thus far, Lagerlöf's story corresponds with Ahmed's analysis: 'a cannibalistic fantasy, of being incorporated into the body of the other, is crucial to the politics of fear: fear works by establishing others as fearsome insofar as they threaten to take the self in' (Ahmed, 2014, 64). The fear of being eaten pervades Lagerlöf's story, but it simultaneously instigates the creation of a morality of social motherhood through a complicated psychological process.

Akka first gives Nils advice on how to survive the beasts of prey: if Nils helps the smaller animals, they will help him in return by providing information and showing him where to hide. In the second step, his honour is at stake, when Nils is tricked into overcoming his fear to prove himself. He is challenged and wants to refute any condescending judgement - providing help while trying to assert himself. Nils only helps by mistake, and although he does express a wish to assist the greylag goose, Finedown, this is not due to any ethical conviction, but because he is overwhelmed by her beauty. At this stage, helping others does not come naturally to Nils and requires a reason. In the third step, help is motivated by habit: Nils has become so accustomed to helping the animals that he helps Father Bear even against his own interest. It takes several months before an ethical motive is provided: it is 'despicable [...] to let a friend down' (Lagerlöf II, 2013, 122). ${ }^{4}$ Fear and vulnerability are the foundation on which the social contract will be built; in this respect, Lagerlöf's story corresponds with a long liberal tradition beginning with Hobbes, Locke and Rousseau. However, as Carole Pateman remarks, the classical social contract theorists 'all tell patriarchal stories' (Pateman, 1988, 41). Lagerlöf's story, in contrast, is feminist. Fear certainly forms boundaries in Nils Holgersson, but an insight into the precariousness of life also encourages care across the very same borders. While fear establishes boundaries in this affective economy, it simultaneously functions as a means to transgression.

\section{Citizenship and transgression}

The morals of citizenship are further anchored in an exposition of different forms of government. As was often the case in Swedish nineteenth-century nationalist literature, the king, in this case, Gustav Vasa, is the cause of the argument (Bohlin, 2016, 72), although his presence is limited to a subordinate clause, and the people of Dalecarlia, dressed in their beautiful national costumes, are portrayed as royalty in the eyes of Nils. The ancient notion of royalty is more resolutely dismissed in the next episode. The feudal swan people are organised according to rank around the king and queen, and they attack the tame Mårten Gander because his white feathers appear to be an attempt to upset the hierarchy. Marrten is saved from the antidemocratic swans by a flock of small birds, individually weak but together strong. 'The Legend of Uppland' reveals that meritocracy is the best model, as Uppland, being the poorest of all the Swedish provinces, had to beg the other provinces for their unwanted refuse. Nevertheless, these bits and pieces were so well utilised that the other provinces had to acknowledge Uppland to be the 'wisest and most able' of them all, and to choose the king from Uppland and found the capital there. The chapter concludes with a moral: 'And that is just as it

\footnotetext{
${ }^{4}$ Since my focus is on Lagerlöf's original text and not on translations in her own time, I will throughout the article use Peter Grave's recent translation, Nils Holgersson's Wonderful Journey through Sweden - the first complete translation into English.
}

Tijdschrift voor Skandinavistiek 36(2), 2018/19 (cc)) EY

Except where otherwise indicated, the content of this article is licensed and distributed under the terms of the Creative Commons Attribution 3.0 License, which permits unrestricted use, distribution, and reproduction in any medium, provided the original work is properly cited. 
should be, for even today wisdom and ability are what transform beggars into princes' (Lagerlöf II, 2013, 104). The next episode, set in the university city of Uppsala, where 'learning [...] governs' (Lagerlöf II, 2013, 115), puts this meritocratic order into concrete form. When the reader finally meets the king, monarchy is severely undermined by democratic meritocracy, and his task in the story, as Thorup Thomsen notes (2007, 95f), will be to praise the capital Stockholm as a home for the entire nation, a folkhem.

However, the imagined community that Lagerlöf's book aims to forge is built on social morals conveyed by a migrating bird, suggesting that the unity formed by the constitution is based on transgression. Akka not only crosses the borders of different countries, but also embraces different species. The epitome of social motherhood is conveyed in her attempt to assimilate the eagle Gorgo into the goose community. She finds the orphaned baby eagle and has the opportunity of 'being rid of this gang of predators forever. However, at the same time it went against the grain not to help a deserted chick' (Lagerlöf II, 2013, 152). The social experiment requires that they both overcome their instincts. The baby is 'repulsive' to Akka (Lagerlöf II, 2013, 152), while Gorgo is fed fish and frogs - appalling food for an eagle. Nevertheless, Gorgo learns to recognise Akka as his mother and 'Akka loved him as if he really was her own offspring' (Lagerlöf II, 2013, 153). Problems arise when the other birds are frightened of Gorgo because of his appearance, which offends and infuriates him. In the end, he must come to terms with his nature as an eagle and leave the geese. Akka is mortified by the failure of her assimilation project and refuses to remain friends, but this is clearly a mistake. In Lagerlöf's national community, love must overcome all differences, and they become friends once more through Nils's mediation, while Nils himself proves that he has learnt the lesson of social motherhood by helping their old enemy Smirre Fox to escape captivity.

After four months as an elf, Nils has developed, in the words of Ellen Key, 'an immediate feeling for all that is weak and in need'. The story ends as Nils regains his original form, but he remains afraid due to habit. 'And then he would immediately laugh at himself and be happy that he was now tall and strong and big and had no need to be afraid of anything' (Lagerlöf II, 2013, 349). Fearless independence is no longer a problem because, in contrast to Mowgli, fear has taught Nils to use his strength to care for others.

According to Lagerlöf, dependence is the necessary source of responsible independence. Nils's progress depicts a psychologically informed method of how to develop moral virtues in several steps, initially motivated by self-preservation, then self-assertion, habit, and finally by an ethic of love. The story also portrays different forms of government, opting for democratic rule intent on creating a home for the people. The nation-building function of fear is to balance the power struggle for a citizen's right to recognition with an insight into the vulnerability of life and the need for transgressive love. This is Lagerlöf's contribution to the folkhem, conveyed by a migratory bird with multiple homelands.

\section{Reference list}

Ahlström, G. ([1942] 1958). Den underbara resan. En bok om Selma Lagerlöfs Nils Holgersson. Stockholm: Bonniers förlag.

Ahmed, S. ([2004] 2014). The Cultural Politics of Emotion. Edinburgh: Edinburgh University Press.

Tijdschrift voor Skandinavistiek 36(2), 2018/19 ((c)) EY

Except where otherwise indicated, the content of this article is licensed and distributed under the terms of the Creative Commons Attribution 3.0 License, which permits unrestricted use, distribution, and reproduction in any medium, provided the original work is properly cited. 
Altén, T. (1983). Nils Holgersson och folkhemmet. Svensklärarföreningens årsskrift 1983, 1637.

Berggren, H. \& Trägårdh, L. (2015). Är svensken människa? Gemenskap och oberoende i det moderna Sverige. Stockholm: Norstedts Förlag.

Berry, C. (2014). Journeys into English. An overview of the English-language versions of Nils Holgersson and anglophone academic discourse. In H. Forsås-Scott, L. Stenberg \& B. Thorup Thomsen (Eds.), Re-Mapping Lagerlöf. Performance, Intermediality, and European Transmissions (pp. 273-288). Lund: Nordic Academic Press.

Bohlin, A. (2016). Den svenska 1840-talsromanen som nationell kartografi. Samlaren, 137, 5886.

Bohlin, A. (2008). Röstens anatomi. Läsningar av politik i Elin Wägners Silverforsen, Selma Lagerlöfs Löwensköldtrilogi och Klara Johansons Tidevarvskåserier. Umeå: Bokförlaget h:ström.

Desmidt, I. (2001). En underbar färd på språkets vingar: Selma Lagerlöfs Nils Holgersson $i$ tysk och nederländsk översättning/bearbetning. Universiteit Gent.

Edström, V. (2002). Selma Lagerlöf. Livets vågspel. Stockholm: Natur och Kultur.

Elenius, L. (2005). Selma Lagerlöf och Norrland. Nationella idealbilder i Nils Holgerssons underbara resa. In M. Karlsson \& L. Vinge (Eds.), I Selma Lagerlöfs värld (pp. 182-209). Stockholm/Stehag: Symposion.

van Elswijk, R. (2014). Nils in the Netherlands. Selma Lagerlöf in Dutch and Frisian, 19111921. In H. Forsås-Scott, L. Stenberg \& B. Thorup Thomsen (Eds.), Re-Mapping Lagerlöf. Performance, Intermediality, and European Transmissions (pp. 261-272). Lund: Nordic Academic Press.

Hartlová, D. (2014). Selma Lagerlöf's story in Czech. In H. Forsås-Scott, L. Stenberg \& B. Thorup Thomsen (Eds.), Re-Mapping Lagerlöf. Performance, Intermediality, and European Transmissions (pp. 245-260). Lund: Nordic Academic Press.

Heggestad, E. (2012). Nils Holgerssons underbara resa över världen. In J. Svedjedal (Ed.), Svensk litteratur som världslitteratur. En antologi (pp. 101-115). Uppsala: Avdelningen för litteratursociologi, Uppsala universitet.

Key, E. ([1903] 1923). Livslinjer I:II. Kärleken och äktenskapet. Stockholm: Albert Bonniers förlag.

Kipling, R. ([1894]1900). The Jungle Book. London \& New York: Macmillan and co.

Kipling, R. (1895). The Second Jungle Book. London \& New York: Macmillan and co.

Lagergren, F. (1999). På andra sidan välfärdsstaten. En studie i politiska idéers betydelse. Stockholm/Stehag: Symposion.

Lagerlöf, S. ([1906-1907] 2013), Nils Holgersson's Wonderful Journey through Sweden. Vol. I-II. Transl. P. Graves. London: Norvik Press.

Lindén, C. (2002). Om kärlek. Litteratur, sexualitet och politik hos Ellen Key. Stockholm/Stehag: Symposion.

Nikolajeva, M. (1991). Selma Lagerlöf ur ryskt perspektiv. Sunne: Selma Lagerlöf-sällskapet.

Nordlund, A. (2005). Selma Lagerlöfs underbara resa genom den svenska litteraturhistorien 1891-1996. Stockholm/Stehag: Symposion.

Pateman, C. (1988). The Sexual Contract. Stanford: Stanford University Press.

Tijdschrift voor Skandinavistiek 36(2), 2018/19 (cc)

\footnotetext{
Except where otherwise indicated, the content of this article is licensed and distributed under the terms of the Creative Commons Attribution 3.0 License, which permits unrestricted use, distribution, and reproduction in any medium, provided the original work is properly cited.
} 
Smedberg Bondesson, A. (forthcoming 2018). Mapping shame and guilt: Inner and outer landscapes in The Adventures of Pinocchio and The Wonderful Adventures of Nils. In G. Larsen \& R. Rasmussen (Eds.), Shame in Literature.

Smedberg Bondesson, A. (2016). Nils Holgerssons resa genom seklet och runt jordklotet. Reception. Tidsskrift for nordisk litteratur, 75, 88-97.

Sundmark, B. (2009). Citizenship and Children's Identity in The Wonderful Adventures of Nils and Scouting for Boys. Children's Literature in Education, 40, 109-119.

Sundmark, B. (2008) Lagerlöf's Legacy: An Hundred Years of Writing the Nation. Bookbird: A Journal of International Children's Literature, 46, 14-21.

Surmatz, A. (2014). Nils Holgersson and a Japanese animated series. In H. Forsås-Scott, L. Stenberg \& B. Thorup Thomsen (Eds.), Re-Mapping Lagerlöf. Performance, Intermediality, and European Transmissions (pp. 163-180). Lund: Nordic Academic Press.

Thorup Thomsen, B. (2007). Lagerlöfs litterare landvinding. Nation, mobilitet og modernitet $i$ Nils Holgersson og tilgreensende tekster. Amsterdam: Scandinavisch Instituut.

Weidel, G. (1972). Ellen Key och Selma Lagerlöf. Väderstad: Ellen Key-sällskapet.

\section{Biographical note}

Anna Bohlin is Associate Professor in Comparative Literature at Uppsala University, researcher at the Department of Ethnology, History of Religions and Gender Studies, Stockholm University, and førsteamanuensis in Nordic Literature, at the University of Bergen. Bohlin's research concerns the intersection between literature and politics, in particular emancipatory theory. After the PhD thesis, Anatomy of Voice. Readings of Politics in Silverforsen by Elin Wägner, the Löwensköld trilogy by Selma Lagerlöf and Klara Johanson's causeries in Tidevarvet (2008, in Swedish), she has primarily published articles on the nineteenth-century Swedish feminist Fredrika Bremer and is currently working on the project 'Enchanting Nations: Commodity Market, Folklore and Nationalism in Scandinavian Literature 1830-1850', funded by The Swedish Foundation for Humanities and Social Sciences.

Tijdschrift voor Skandinavistiek 36(2), 2018/19 (co) EY 